\title{
Orchestration of the National Anthem of the USSR. Recent Discoveries in Russian Archives
}

\author{
Elena Artamonova \\ University of London \\ London, United Kingdom \\ mup01ea@gold.ac.uk
}

\begin{abstract}
A commission to orchestrate the National Anthem of the USSR in 1943 has been neither widely publicised nor researched. The aim of this paper is to reestablish the sequence of events from the moment when Aleksandrov's song was proclaimed the Anthem and to reevaluate the role of the Russian composer Sergei Vasilenko in its orchestration. The analysis and discussion of these subjects rely heavily on unpublished and little-explored materials on Vasilenko from the archives in Moscow.
\end{abstract}

Keywords-National Anthem; orchestration; Politburo; contest; instrumentation

\section{INTRODUCTION}

A commission to orchestrate the National Anthem of the USSR in 1943 has been neither widely publicised nor researched, though the Russian composer Sergei Vasilenko prepared an in-depth article for the press that illustrated his meeting with Stalin and the members of the Politburo, who authorised Vasilenko's orchestration for the national radio broadcast. The author of this paper was privileged to work with Vasilenko's archives, research his publications in libraries in London and Moscow and was fortunate to find a number of his unknown works and documents. The aim of this paper is to re-establish the sequence of events from the moment when Aleksandrov's song (his former Hymn of the Bolshevik Party that in its turn was adopted from his older song Life Has Become Better) was proclaimed the Anthem and to re-evaluate the role of Sergei Vasilenko in its orchestration.

\section{SeRGeI VASILENKO}

Sergei Nikiforovich Vasilenko (1872-1956) had a long and distinguished career as a composer, conductor, and pedagogue based in Moscow in the first half of the twentieth century. For almost fifty years (1906-41 and 1943-56), he held the position of Professor of Instrumentation and Composition at the Moscow Conservatoire and taught Nikolai Golovanov, Leonid Polovinkin, Nikolai Roslavets, Aleksandr Aleksandrov, Anatolii Aleksandrov, and many other students who became internationally known performers and composers. Vasilenko gained recognition as a composer with a special emphasis on Russian national traditions and history, including Old Believers' chant and folk music and symbolic and mystical themes influenced by the Silver Age aesthetic. His musical language was rooted in the traditions of the nineteenth-century Russian composers, particularly his teacher Taneev and Scriabin, but also adding hints of early modernism. While Russian culture was the inspirational source of Vasilenko's musical resourcefulness and being, his intellect and erudition won him recognition among his contemporaries. Some critics called him 'a profound analyst' for his comprehension of Russian music along with the works of Wagner, French Impressionists, and other composers [1]. His depth of knowledge of instrumental colours and their combinations, technical and sonorous possibilities, as well as his professionalism in their application allowed Vasilenko to employ, operate, and mix contradictory idioms with dynamism and expression. $\mathrm{He}$ died in 1956, leaving an extensive list of compositions, including five symphonies; concertos for balalaika, trumpet, cello, harp, clarinet, piano and horn; a number of shorter orchestral works (including two Chinese Suites and an Exotic Suite); works for stage, including seven operas and seven ballets; chamber and instrumental music; and songs, choruses, folksong arrangements and more.

In the second half of the twentieth century, Vasilenko's music has fallen from view and he has been perceived as a conformist and inconsequential Soviet composer. The recent discoveries of unpublished documents reveal Vasilenko to be a decent man and a talented musician whose search for a niche within the culture of Soviet music forced him to keep his true musical writings secret from the public in a drawer of his desk. They represent Vasilenko as a master of composition and instrumentation with a diversity of stylistic and instrumental approaches, harmonic and rhythmic language, an exquisite palette of sound colour and a considered approach to the form, articulations and dynamics [2]. At the same time, some of his compositional accomplishments were primarily shaped and determined by the political demands of the Soviet rule and its state commissions. Vasilenko's roots in the Russian aristocracy, which potentially could have had fatal consequences in the new proletarian society, and the need to provide for the family and maintain its social status, obliged Vasilenko to avoid unnecessary political risks. As a result of Vasilenko's formal obedience many facts about him have been either misinterpreted in publications or kept under wraps until recently. 


\section{ANTHEM CONTEST}

The replacement of the Internationale by the anthem known as the State Anthem of the Soviet Union in December 1943 came as no surprise. The Internationale of foreign French origin could no longer represent the country at the peak of its Sacred War against the Nazis. Its text was outdated and simply inappropriate. The archival protocol of the Politburo TSK VKP(B) (the Executive Committee of the Communist Party of the Bolsheviks) 'About the Anthem of the USSR' states the following:

The present Anthem of the USSR the Internationale does not correspond with the reality in the Soviet state because:

- It only calls for those under exploitation to fight, for emancipation from violence and for creation of a new world. As such, it references aims that workers in the Soviet Union have already achieved.

- Its content does not reflect the foundational changes, which happened in our country thanks to the Soviets. It does not express the socialistic essence of the Soviet state. For these reasons the Internationale remains a recognised hymn for workers in capitalist countries, who are facing the fight for their freedom from capitalist slavery. [...]

Voted: comrades Stalin, Molotov, Kalinin, Voroshilov, Mikoian, Kaganovich, Beria, Malenkov, Shcherbakov and Voznesenskii - yes. Approved 25 October [3].

A new anthem written by a Soviet author had to be created as a gesture intended to demonstrate the unity of all its citizens and to glorify the achievements of the state led by Lenin and Stalin. The anthem contest was opened to all in order to achieve this goal. It was regarded as a national duty to participate, whether one wanted or not, and some composers as well as poets offered a few anthems. By 25 October 1943 the lyrics by Mikhalkov and El'-Registan were approved, although for another two months the poets kept amending their lyrics following Stalin's personal recommendations. On 14 December Stalin authorised the final text of their lyrics and made his final choice in favour of the music written by Aleksandr Aleksandrov, though the official announcement of his decision was published in the newspaper Pravda only on 22 December 1943. The immense scale of the contest is seen in the endless list of participants. In a decree published in Pravda and other newspapers on 5 January 1944, the Sovet Narodnykh Komissarov USSR (the Council of People's Commissars) highly praised 165 composers and 41 poets, who took part in the contest. Apart from official commendations, all participants received financial awards with prizes ranging from 4,000 and 8,000 roubles to 100,000 roubles. Top three prizes were awarded to both authors of the text of the new anthem, El'-Registan and Mikhalkov, and to its composer Aleksandrov. Those composers whose music was selected for choral and orchestral auditions received 8,000 roubles for every entry of an anthem they prepared. All other composers and poets received 4,000 roubles for every entry of their anthem.

\section{ORCHESTRATION OF THE ANTHEM}

The commission to orchestrate the National Anthem of the USSR, written by Vasilenko's former student Aleksandr Aleksandrov, provided for Vasilenko's social security in the last decade of his life. This was a risky bold step for all people involved, because everything depended not only on the quality of the final product but on its aptness for Stalin. Thus, Viktor Knushevitskii (1906-1974), a former student of both Aleksandrov and Vasilenko, orchestrated the entries for the final contest round of anthems. Stalin liked Aleksandrov's music, but criticised its orchestration [4]. This was the moment when Vasilenko was called to step in, though he never mentioned in any of his documents that he was replacing someone else. Vasilenko only briefly mentioned that Aleksandrov asked him to take on this work, because in the opinion of Aleksandrov, Vasilenko was the best [5]. This approach characterises Vasilenko as a wise decent man, who did not allow himself to stoop to meanness by smashing people's heads against each other. He boldly followed the same principle in his speech at the plenum of the USSR Union of Composers in 1948 that was held after the decree of Zhdanov against the composers guilty of formalism [6].

\section{THE PRINCIPLES OF INSTRUMENTATION}

From 1 January 1944 until the collapse of the Soviet Union in December 1991, the orchestral recording of the National Anthem started all the radio and TV broadcasts in the USSR. Vasilenko's name was publicly announced in connection with the Anthem only once. On 8 January 1944, a newspaper Literatura i iskusstvo [Literature and Art] published a series of articles on its front page about the first performance of the Anthem of the USSR, including a brief but detailed article by Vasilenko on the principles of his instrumentation of the Anthem. Vasilenko kept the focus of his article primarily on the analysis of his instrumental approach that in his opinion brought in a special orchestral colouring.

- ... The main aim of an orchestrator is to reveal as brightly and deeply as possible the musical content of a composition. The position of inner and outer voices is set in a broader format compared to a piano arrangement, because there is a range of rich orchestral possibilities for it.

- ... The anthem must sound powerful and at the same time simple; solemn and as a chorale but without any extra movement of middle voices. This is the distinctive feature of the instrumentation for a symphony orchestra.

- Bright and at the same time simple sonority could be achieved with different methods, for example, with the use of clarinets and oboes in the high register, which is unusual. Together with the first and second violins they bring a ringing effect.

- It is important that the chorus sounds with a special power. Thus, in the first phrase 'Be glorious our free 
Motherland' the orchestra is brought to a more intensive register.

- The culmination is reached in the third line of the chorus: 'Banner of the Soviets, Banner of the people...' Therefore, two bars before this phrase the orchestra needs to give a further boost, which is achieved in the instrumentation by the intensification of the higher register with simultaneous strengthening of the bases.

- I have learned from my extensive experience to maintain a smooth and broad line of the melody of the anthem, with a steady chorale-like sound of the middle register in the background.... [7]

It is noteworthy that Vasilenko managed to put his points more succinctly than the other authors of the articles, including a conductor Aleksandr Melik-Pashaev, who did not avoid effusive praise describing the text and the music, which was a characteristic feature of the time [8].

\section{Private Audition AND A BanQuet With The MEMBERS OF THE POLITBURO}

The RGALI has Vasilenko's unpublished recollections dated 7 August 1947 about Stalin and the private audition of the Anthem organised for him and the members of the government that took place at the Bolshoi Theatre on 30 December 1943 at $10 \mathrm{pm}$, which was followed by a banquet that Vasilenko managed to leave only at 6am the following morning [9]. According to Vasilenko, the anthem was performed in three different arrangements that night: at first, in C major for a men's chorus with piano sang by the Red Army Choir and accompanied by Aleksandr Aleksandrov, followed by the arrangement by Nikolai Ivanov-Radkevich for a wind orchestra performed three times by the Red Army Band conducted by Semen Chernetskii and finally, in the arrangement by Sergei Vasilenko for a symphony orchestra in $\mathrm{E}$ flat major performed by the orchestra of the Bolshoi Theatre conducted by Aleksandr Melik-Pashaev. After the performances, an officer disturbed the complete silence in the hall. He came on the stage and called up Vasilenko to Stalin's box: 'Comrade Vasilenko, please come here!' At the banquet, Vasilenko sat opposite Stalin, who was sitting next to the members of the Politburo Molotov, Beria and Kalinin as well as Aleksandr Shcherbakov (the First Secretary of the Moscow Regional Party Committee), Mikhail Khrapchenko (the First Chairman of the Committee of the Arts Council of Ministers of the USSR), Chernetskii and Melik-Pashaev. On Vasilenko's side of the table were Aleksandrov, IvanovRadkevich and the authors of the text of the Anthem Sergei Mikhalkov and Gabriel El'-Registan. The manuscript has many corrections authorised by Vasilenko that polished his phrasing and content, which suggests that he intended this text for publication. The speech of Stalin addressed to Vasilenko in front of the members of the government, including Molotov, Beria, Kalinin, and Vasilenko's fellow colleagues, the conductors of the Bolshoi Theatre Golovanov and Melik-Pashaev, and the poets Mikhalkov and El'Registan, is worth quoting at length. Stalin not only expressed his gratitude to Vasilenko for making his orchestration intelligible for the masses but also explained the hostile attitude of the Bolsheviks to the cultural heritage and its representatives.

... I will not talk about Aleksandrov - he is known to everyone, and his teacher and the conductors, who are present here, know him even better. We will not talk about the music, as we are not specialists, but we do have right to talk about orchestration!1 Why? Because it sounds real and bright and expresses everything that the music has; every listener that does not have a special music background can justify this. Aleksandrov is ours; he has been working for us for a long time. Thus, I would like to say about those, who came to help us. At the beginning of the Revolution, there was a different attitude to the old masters, this attitude was incorrect...There was a saying: we do not need the heritage of the past; let us create everything new and unprecedented with our young people. This was wrong, as there were many other ugly occurrences, which were unavoidable at the beginning of the Revolution. How is this possible that science, literature, music and fine arts do not rely on the experiences if not of previous years but of centuries? Why would old masters not come with their experience and knowledge to teach young people how to build a new life? Thus, the comrade came to help us and what a brilliant result we have achieved! He is far from being young, but I can see that he is full of strength and energy...Let us wish him many more years of health and creativity, so that he would not only provide us with his compositions, but would teach his mastery to our young people! To your health, Sergei Nikiforovich! ... [9]

This skilfully staged speech was full of compliments as well as repentances for the past acceptable only to naive and inexperienced people, a category to which none in the audience belonged. After the toast, Stalin continued in a fatherly way by drawing a line of succession, which thrilled Vasilenko to the core.

... Here we are seeing a rare and touching connection: in a row, there are sitting comrades Vasilenko, Aleksandrov and Ivanov-Radkevich, who made the military instrumentation, which we all liked. Aleksandrov was taught by Professor Vasilenko, Ivanov-Radkevich by Aleksandrov. This means: a father, son and grandson. ... [9]

Vasilenko asked for the floor and followed this phony narrative by praising Stalin for his support of arts.

... His participation in the arts is revealed not only in the creation of the Anthem; he looks keenly and untiringly after Russian art in general. And if now it is indeed possible to work productively in all fields of the arts, we are totally obliged for this to Iosif Vissarionovich. ... [9]

Vasilenko emphasised that he did not quote his speech in detail but today it still conveys the meaning of his political compliance with the supreme authority in art.

Stalin liked to refer to himself in the royal plural. 


\section{ROGAL' LEVITSKII'S ORCHESTRATION}

According to the sources on Dmitrii Rogal'-Levitskii, a former student of Vasilenko and his colleague, listed below, he re-orchestrated Aleksandrov's national anthem under Stalin's order and supervision in spring 1944 [10]. One should not doubt that this re-orchestration did take place, though Vasilenko was left unaware of this. At the same time, one should question how much Rogal'-Levitskii altered or changed the orchestration. According to Rogal'-Levitskii's article listed below, he added harps and bells, enhanced the lower strings with pizzicato phrases, and intensified the texture and dynamics toward the end of the anthem. Nevertheless, Vasilenko did not notice any changes when he listened to the anthem in the presence of Rogal'-Levitskii. Vasilenko praised the orchestration as his own and Rogal'Levitskii did not dare to comment that he re-orchestrated it. The scores of both orchestrations would have helped to answer this query. However, Vasilenko's archives do not have a copy of his orchestration and its location remains unknown at present. The supposition of the author of this article with regard to the limited scope of changes in the reorchestration of the anthem is partly confirmed in the words of Stalin addressed to Rogal'-Levitskii, which were quoted in the article of Vladimir Lakshin listed below: 'You have taken the best of what it [the orchestration] had before and combined it with your own fine ideas, which made the outcome as it was required.' This article published in 1991 was based on the previously unpublished memoirs of Rogal'Levitskii dated 11-20 April 1944 written in Moscow that were passed after his death in 1962 to Vladimir Lakshin, the son of a family friend. The memoirs describe the audition of the new orchestration of the National Anthem and the following banquet that took place in spring 1944 in the presence of Stalin and the other members of Politburo, which was conducted in a similar format to the one described by Vasilenko in his article. Rogal'-Levitskii did not specify the date of the audition, but the news, which Stalin received during the night banquet about the victories of the Red Army that reached the state frontier on a front of 85 kilometres at the river Prut and liberated the town of Kamenets-Podolsk in Ukraine, point to 26 March 1944.

\section{CONCLUSION}

Vasilenko was truly proud of his orchestration. In his unpublished writing dated between 1949 and the early 1950s, he expressed the feeling of honour for being entrusted with this mission of orchestrating the national anthem [11]. His formal obedience most certainly helped him to stay alive and carry on his professional activities. One may say that Stalin was right to a degree in saying that the result of a joint collaboration of Vasilenko and Rogal-Levitskii was brilliant as it suited not only Soviet but also post-Soviet rule. As one of the paradoxes of our time, in 2000, the National Anthem of the USSR with new lyrics written by the same author, Mikhalkov, became the National Anthem of the Russian Federation that continues to live on in Russia today.

\section{REFERENCES}

[1] Evgeny Braudo, The 45 Anniversary of the Creative Activities of the Merited Arts Worker S.N. Vasilenko, 18. Housed in RGALI, fund 2024 , op. 1, ed. khr. 37. All quotations from Russian sources and publications used in this paper have been translated by the author, Elena Artamonova.

[2] Elena Artamonova, Unknown Sergei Vasilenko and His Viola Compositions: Recent Discoveries in Russian Archives, Journal of the American Viola Society 1, vol. 28 (2012): 33-47. http://eprints.gold.ac.uk/7604/ Elena Artamonova, Liner Notes, Sergei Vasilenko and the Viola, 2-11. In Sergei Vasilenko. Complete Music for Viola and Piano, Elena Artamonova (viola) and Nicholas Walker (piano), Toccata Classics TOCC 0127, 2011, compact disc. http://www.toccataclassics.com/cddetail.php?CN=TOCC0127

[3] Leonid Maksimenkov, ed., Music Instead of Muddle. Composers and Musicians in the Land of the Soviets, 1917-1991. Documents, Moscow: Demokratia, 2013, pp. 228-229.

[4] Laurel E. Fay, Shostakovich: A Life, New York: Oxford University Press, 2005, p. 139. Dmitry Shostakovich, Testimony, Solomon Volkov (ed.), London: Faber \& Faber, 2005, pp. 201-205. Boris Gasparov, Five Operas and a Symphony: World and Music in Russian Culture, New Haven, London, Yale University Press, 2005, pp. 214-218.

[5] Sergei Vasilenko, Pages of Reminiscences, (Moscow, Leningrad: State Musical Publishing, 1948), 19.

[6] Sergei Vasilenko, My Speech at the First Plenum, Housed in GNMCMC, fund 52, ed. khr. 1536, pp. 1-14.

[7] Sergei Vasilenko, Principles of Instrumentation], Literatura i Iskusstvo, Jan. 8, 1944, Section: In the Council of the People's Commissars of the USSR.

[8] Aleksandr Melik-Pashaev, First Performance of the Anthem, Literatura i Iskusstvo, Jan. 8, 1944, Section: In the Council of the Peoples Commissars of the USSR.

[9] Sergei Vasilenko, I.V. Stalin. Memoirs. Chapters. Housed in RGALI fund 2871 , op. 1, ed. khr. 72, p. 1.

[10] Olga Digonskaia, Interview by the author, Moscow, July 13, 2012 Dmitrii Rogal'-Levitskii, Pages of Reminiscences, State Anthem, Olga Digonskaia (ed.), Musical Academy (1998), pp. 159-175. Vladimir Lakshin, Anthem. About the 281st Author of the Anthem. Dmitry Rogal-Levitsky, Nezavisimaia Gazeta, February 12, 1991, Archive, 5.

[11] Sergei Vasilenko, Autobiographic Writings, Housed in RGALI, fund 2579 , op. 1 , ed. khr. 408 , p. 23. 